\title{
Holocene palaeoenvironmental evolution of Saltés Island (Tinto and Odiel estuary, SW Spain) during the Roman period (1st century $B C-5$ th century AD)
}

\author{
María L. González-Regalado ${ }^{1}$ Paula Gómez ${ }^{1,8}$ • Francisco Ruiz ${ }^{1,8} \cdot$ Luis M. Cáceres $^{1,8} \cdot$ María J. Clemente $^{1,8}$. \\ Joaquín Rodríguez-Vidal ${ }^{1,8}$. Antonio Toscano ${ }^{1,8}$. Guadalupe Monge ${ }^{2}$ - Manuel Abad ${ }^{3,8} \cdot$ Tatiana Izquierdo $^{3,8}$.

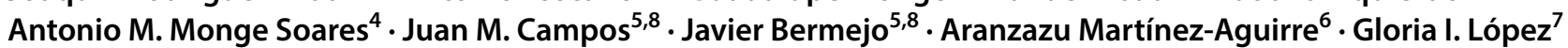

Received: 15 January 2018 / Accepted: 6 October 2018 / Published online: 22 October 2018

(c) Springer Nature Switzerland AG 2018

\begin{abstract}
A multidisciplinary analysis of Holocene sediments from Saltés Island (Tinto-Odiel estuary, SW Spain) has allowed to differentiate eigth sedimentary facies, according to their textural characteristics, internal structure, paleontology and archaeological content. Its interpretation and the chronological datings carried out reconstruct a transition from a sandy tidal plain to a final occupation by a Roman salting (cetaria) between the 1 st century BC to 5 th century A. This evolution includes the deposit of washover fans derived from high-energy events between the 1st century BC to 3th century AD. The integration of these new data with others from previous research has allowed partially complete the palaeoenviromental reconstruction of the marine domain of the Tinto-Odiel estuary.
\end{abstract}

Keywords Sedimentary facies $\cdot$ Palaeontology $\cdot$ Archaeology $\cdot$ Roman evolution $\cdot$ Holocene palaeoenviromental reconstruction $\cdot$ Tinto-Odiel estuary

\section{Resumen}

El análisis multidisciplinar de sedimentos holocenos procedentes de la isla Saltés, situada en el estuario de los ríos Tinto y Odiel (SO de España), ha permitido diferenciar ocho facies sedimentarias, de acuerdo a sus características texturales, estructura interna, contenido paleontológico y restos arqueológicos presentes. Su interpretación y las dataciones cronológicas efectuadas han permitido reconstruir una transición desde una llanura mareal arenosa a la ocupación final de la zona por una factoría romana de salazones (cetaria) entre los siglos I BC y V AD. Esta evolución incluye el depósito de washover fans derivados de la acción de eventos de alta energía entre los siglos I BC y III AD. La integración de estos nuevos datos con otros procedentes de investigaciones previas ha permitido completar parcialmente la reconstrucción paleoambiental del dominio marino del estuario de los ríos Tinto y Odiel.

Palabras clave Facies sedimentarias $\cdot$ Paleontología $\cdot$ Arqueología $\cdot$ Evolución romana $\cdot$ Reconstrucción paleoambiental holocena $\cdot$ Estuario Tinto-Odiel

\section{Introduction}

In the last 20 years, numerous studies were focussed on the Late Holocene geological record of different Spanish estuaries in order to draw the evolution of these complex areas

Francisco Ruiz

ruizmu@uhu.es

Extended author information available on the last page of the article during the last thousands of years. These investigations are usually based on the analysis of continuous cores or exposed sections and the vertical facies distributions and architecture defined in them, as well as in their datings and age models (Dabrio et al. 2000; Ruiz et al. 2004b; Leorri and Cearreta 2004; Pérez-Arlucea et al. 2007; Cearreta et al. 2016; Camacho et al. 2017).

The palaeontological record provides a powerful tool to elucidate the different palaeoenvironments deduced from this stratigraphical record, with special attention to the 
vertical distribution of microfauna. In many cases, benthic foraminifera and, to a lesser extent, ostracods are used to determine changes in sedimentary dynamics, variations in environmental parameters or the impact of pollution on microfaunal assemblages (Pascual et al. 2002; Ruiz et al. 2009; Cearreta 2017). In addition, these microorganisms are useful to detect sedimentary beds (e.g. cheniers, washover fans) derived from the action of high-energy events, such as storms or tsunamis (Luque et al. 2002; González-Regalado et al. 2013; Guerra et al. 2014). These palaeoenvironmental reconstructions are usually improved with the pollen analysis (García Antón et al. 2006; Estiarte et al. 2008).

On the contrary, there are comparatively many less researches that have used the macrofauna for this purpose. For example, mollusks are studied as indicators of historical changes in estuarine-lagoonal systems (Ruiz et al. 2005b, 2008) or as evidence of high-energy events (Gutiérrez-Mas et al. 2009; Gutiérrez-Más 2011). Shell remains of molluks, crustaceans and echinoderms were analyzed in order to establish resource exploitation patterns and environmental conditions of human settlements (Álvarez-Fernández 2015; García-Escárzaga et al. 2017; Gutiérrez-Zugasti 2017).

In addition, the combined geomorphological, radiocarbon dating, archaeological and historical approach permits refining of the age of the coastal dune systems related to estuaries (e.g. Borja et al. 1999), whereas the geochemical analysis of Holocene series can reveal historical and pre-historical phases of metal contamination (Nocete et al. 2005; Carretero et al. 2011). Even with all these contributions, the relationship between geological evolution and human occupation of these coastal areas requires new research for understanding long-term interactions between dynamic littoral ecosystems and human management (e.g. Alonso et al. 2015; Ejarque et al. 2016).

Along the southwestern Spanish coast, there a number of studies have concentrated on the Holocene evolution of this littoral area, suggesting a chronology of events of progradation and erosion based on the radiocarbon dating of shells collected from littoral spits (Zazo et al. 1994; Lario et al. 1995; Goy et al. 1996; Dabrio et al. 1999). The limits for progradation of the main spit units are $6500-4400 \mathrm{cal}$. yr BP, 4200-2550 cal. yr BP, 2300-800 cal. yr BP and $500 \mathrm{cal}$. $\mathrm{yr} \mathrm{BP}$ to the present. These phases are divided by erosional events at 4500-4200 cal. yr BP, 2600-2300 cal. yr BP and 1100-1000 cal. yr BP. Other studies have investigated the geological reconstruction of the Holocene sedimentary evolution based on drill cores (Borrego et al. 1999; Dabrio et al. 2000; Carretero et al. 2002; Ruiz et al. 2005a; Pozo et al. 2010) or the historical and archaeological record of economic activities developed in this area (Campos et al. 2002; Campos 2011; Bermejo et al. 2016), but there is still insufficient knowledge about these geological phases and how this geological evolution conditioned these human activities (e.g. Campos et al. 2015).

In this paper, a multidisciplinary analysis is carried out to determine the geological evolution of Saltés Island (TintoOdiel estuary, SW Spain) during Roman times (1st century $\mathrm{BC}-5$ th century $\mathrm{AD}$ ). Results from facies analysis, dating and paleontology were contrasted with those derived from the archaeological record of this area and the adjacent zones in order to drawn the palaeoenvironmental evolution of this area during this period.

\section{Study area}

\subsection{The Tinto-Odiel estuary}

The Tinto-Odiel estuary is located on the southern Spanish Atlantic coast, at the junction of the Tinto and Odiel rivers (Fig. 1a, b), forming a wide drowned valley system incised into a Pre-Holocene detrital basement. The marine sector of this estuary is a tidal zone with several bodies of salt marshes and bioclastic ridges (e.g. Saltés Island) separated by two main channels (Punta Umbría channel and Padre Santo channel) and protected from the Atlantic Ocean by two sandy spits (Fig. 1c: Punta Umbría, Punta Arenillas).

Tidal regime, wave action and fluvial discharge are the most dominant factors controlling the hydrodynamic processes in this estuary. The tidal regime is mesotidal and semi-diurnal, with a low diurnal inequality (Borrego et al. 1993). Dominant waves come from the south-west, associated with the Atlantic circulation regime. Finally, the sediment discharge of the Tinto-Odiel river system varies seasonally reaching a maximum between December and January, when rainfalls are abundant on the catchments.

Most of the physical and chemical parameters of water, i.e. salinity, temperature, dissolved oxygen and $\mathrm{pH}$ values, undergo significant seasonal variations (IEO 1992; AMA 1993). Thus, during the summer, salinity is nearly constant at $36 \%$, owing to the strong tidal current effect; water temperature is about $26{ }^{\circ} \mathrm{C}$ near surface water; dissolved oxygen content varies from 4 to $6 \mathrm{mg} / \mathrm{l}$, and the $\mathrm{pH}$ values range between 6 and 8 . In winter, partial stratification occurs where Tinto and Odiel rivers meet, and consequently the surface layer of the water column is markedly less saline (even 5\%o) and more acidic ( $\mathrm{pH}=2-5)$ than the bottom layer (salinity $=29-32 \%$ and $\mathrm{pH}=5-7$ ).

\subsection{Saltés Island: brief geomorphological synthesis}

This small island is located on the marine domain of the Tinto-Odiel estuary (Fig. 1c), forming part of the second most important wetland in southern Spain after the Doñana National Park. Since 1983, it is part of a UNESCO Biosphere 


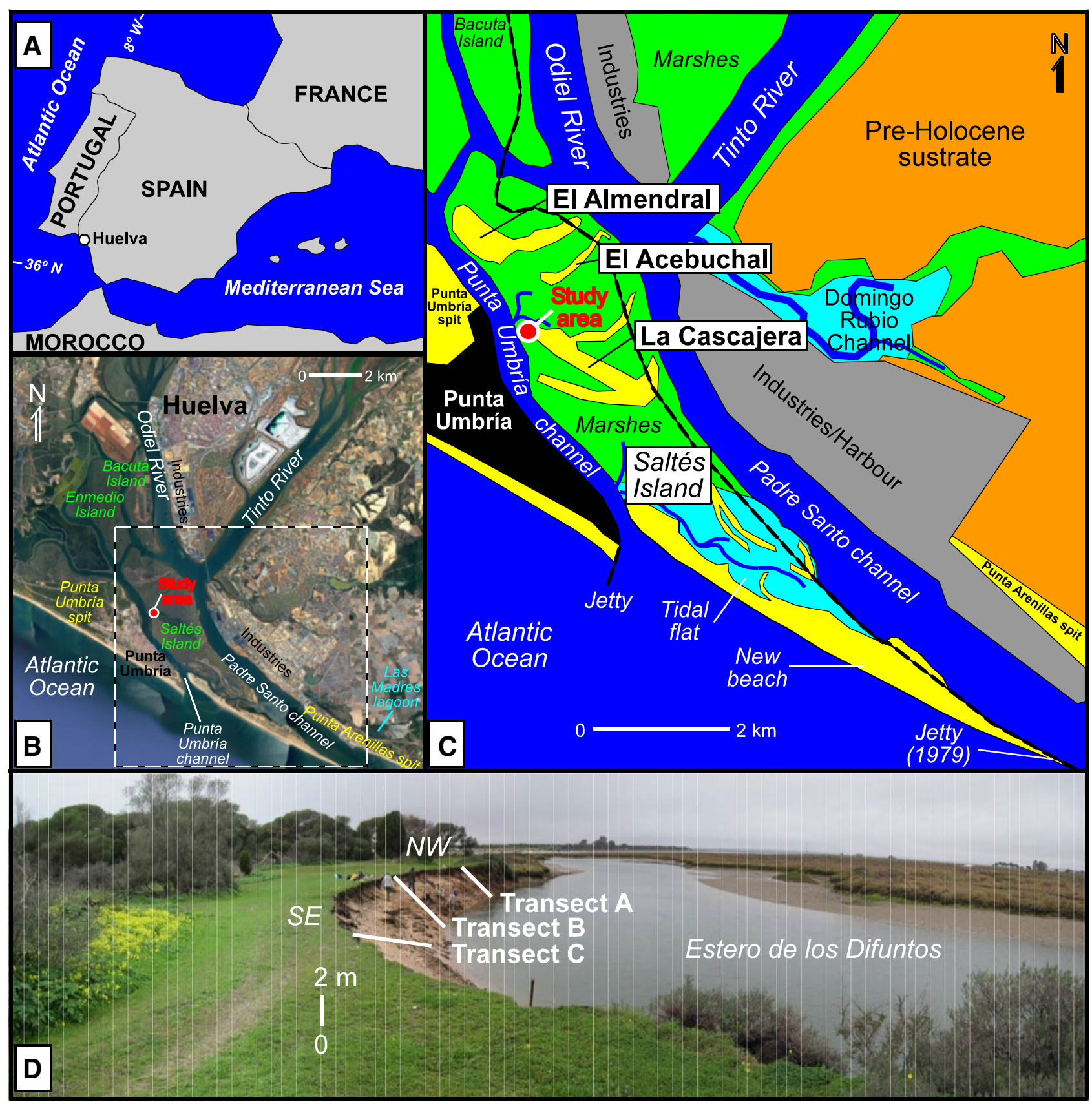

Fig. 1 a, b Location of Saltés Island and the study area; c main geomorphological features of the Tinto-Odiel estuary; d location of the three transects studied

Reserve because of its rich landscape and wildlife, with a wide variety of ecosystems (marshes, ebb-tidal channels, sandy spits, bioclastic ridges) in which more than 270 species of birds have been registered (Gacio and Sayago 2011).

One of its most important geomorphological features is the presence of curved sandy ridges constituted by different generations of cheniers and washover fans (Fig. 1c: El Almendral, El Acebuchal, La Cascajera), with a hook shape related to coastal drift and wave refraction (Figueroa and
Clemente 1979). The surface between these ridges is occupied by salt marshes with a distribution of the vegetation conditioned by the sustrate and the periods of flood. The most abudant species are Spartina marítima, S. densiflora, Salicornia ramosissima, Sarcocornia perennis and Arthrocnemum macrosthachyum (Junta de Andalucía 1991). The southermost part of the island is formed by a wide tidal flat, separated from the town of Punta Umbría by a tidal inlet (Punta Umbría channel). 
The natural sedimentary evolution of this island has been modified due to the construction of a jetty in 1979 (Fig. 1c: $14 \mathrm{~km}$ length; $35 \mathrm{~m}$ width) to protect Huelva harbour, and another smaller jetty ( $1 \mathrm{~km}$ length) adjacent to the town of Punta Umbría to stabilize access to the fishing harbour. One of the most significant geomorphological effects has been the creation of a new wide beach $(<2.5 \mathrm{~km}$ length; $40-50 \mathrm{~m}$ width) attached to the first of them. A review of all the collateral effects produced by these constructions can be consulted in Morales et al. (2004) and Morales et al. (2014).

\subsection{Geoarchaeology of Saltés Island during the Roman period}

Different data obtained from archaeological researchs around Saltés Island permit to draw the history of the Tinto-Odiel river mouth during the Roman period. During the 1 st century BC-1st century AD, an important economic impulse was propiciated by Emperor Augustus (27 yr BC-14 yr AD) and his successors. At this time, Onoba (see location in Fig. 8c) was the main port of this area, with a development of productive, storage and even religious buildings on already consolidated marshes located in the lower areas of the city (Campos 2011). This important Roman site was surrounded by a set of secondary salting factories or cetaria (Fig. 8c: El Almendral, El Eucaliptal) constituted by domestic structures, salting ponds for the exploitation of marine resources and cementeries (Campos et al. 1997, 1999a, 2002).

This period of strong social and economic dynamism ended in the middle of the 3 th century AD. Several salting factories of Onoba were abandoned and numerous pools of this period show signs of deterioration. This crisis also affected El Eucaliptal, with the abandonment of the facilities and the temporary cessation of the occupation of this factory (Campos et al. 2015). Other nearby factories also ceased their activity in this period, in times after Gordian III (238-244 yr AD) (Campos et al. 1999b; Campos and Gómez 2001). This crisis could be due to a great earthquake that devastated the southwestern sector of the Iberian Peninsula between 260 and 290 yr AD. This high-energy event caused great destruction in various Roman cities located near the Gibraltar Strait, such as Baelo Claudia or Carteia (see Fig. 8b for location; Alonso et al. 2004; Silva et al. 2016).

A new economic recovery occurred in the first half of the 4th century AD, with a latent activity both in Onoba and El Eucaliptal and the presence of a large number of small maritime villae with estuarine connection on the margins of the Tinto river (e.g. Domingo Rubio tidal channel; Bermejo et al. 2016). This expansive stage has also been verified in other cetariae of southwestern Spain (Campos et al. 2002).

This period of intense activity ended in the last third of this century or the beginning of 5th century AD. In several archaeological sites (e.g. El Eucaliptal), it has been verified the presence of a level of marine inundation, with sandy, shelly sediments that covered the industrial zones of the settlements, as well as the canals and the decanting tanks (Campos et al. 2015). In addition, numerous buildings collapsed (Bonsor 1928). Some historical sources of doubtful reliability reported a tsunami in 382 AD (De Britto 1609), whereas an event of this nature has been argued to explain the final ruin of Baelo Claudia between 400 and $450 \mathrm{yr}$ AD (Röth et al. 2015) and could therefore have affected the nearby Tinto-Odiel estuary.

\section{Materials and methods}

\subsection{Field}

The chosen study site ( $60 \mathrm{~m}$ long) was an elliptical section exposed by the erosional action of an ebb-tide channel (Fig. 1d: Estero de los Difuntos) at the nortwestern part of La Cascajera sandy ridge (NW Saltés Island), near the Punta Umbría channel. Three transects (Fig. 1d: A-C) were selected with a normal orientation to the tide line. The main features of the sedimentary facies present in each transect (Table 1) were initially described in the field, as well as the vertical situation of each facies in relation to the mean high tide level (Fig. 2). In addition, a surface collection of archaeological remains present in each facies has been carried out.

\subsection{Laboratory}

Forty-four surface sediment samples (1.5 kg dry weight) were collected for textural and palaeontological analyzes by manual picking at outcrop level. Some subsamples $(0.1 \mathrm{~kg})$ were wet sieved through a sieving column $(-1<\boldsymbol{\varphi}<4)$ for determining the grain size distribution (Fig. 3).

Eighteen further subsamples $(1 \mathrm{~kg})$ were separated for the study of the bivalves present at a specific level (Fig. 4). Several taphonomic characteristics were analyzed (articulation, color, bioerosion, possible evidences of human activities on shells) in each subsample.

Forty-four subsamples were separated for foraminiferal analysis (Fig. 5). Ten grams were wet sieved $(0.125 \mu \mathrm{m}$ mesh) using destilled water and dried in an oven at $70{ }^{\circ} \mathrm{C}$. The total foraminiferal population was analyzed at specific level.

\subsection{Chronology}

Three subsamples were selected for dating (Fig. 3: samples A-9, C-1 and C-13). Three pristine shells of Glycymeris, i.e. with no evidence of weathering, wear or breakage, were collected for this purpose. The outermost layer of each individual 


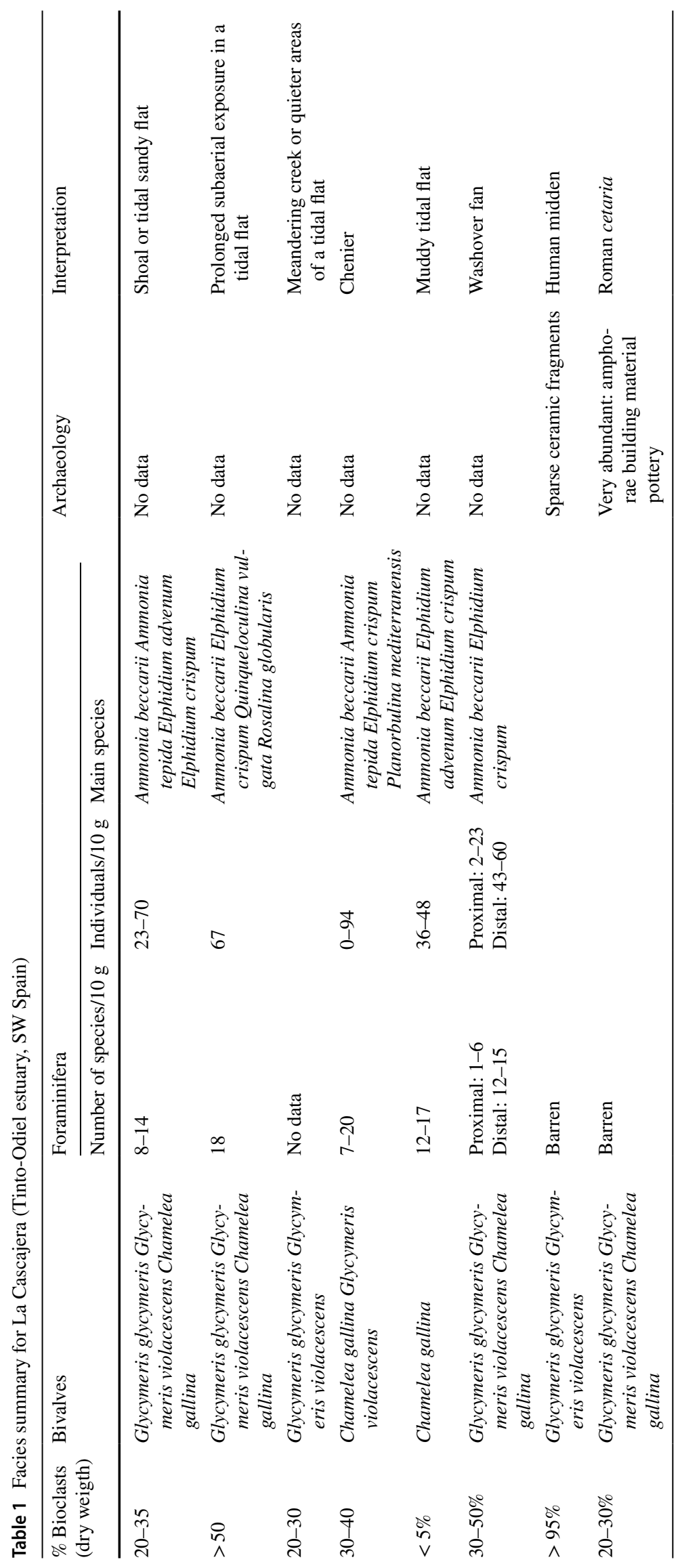




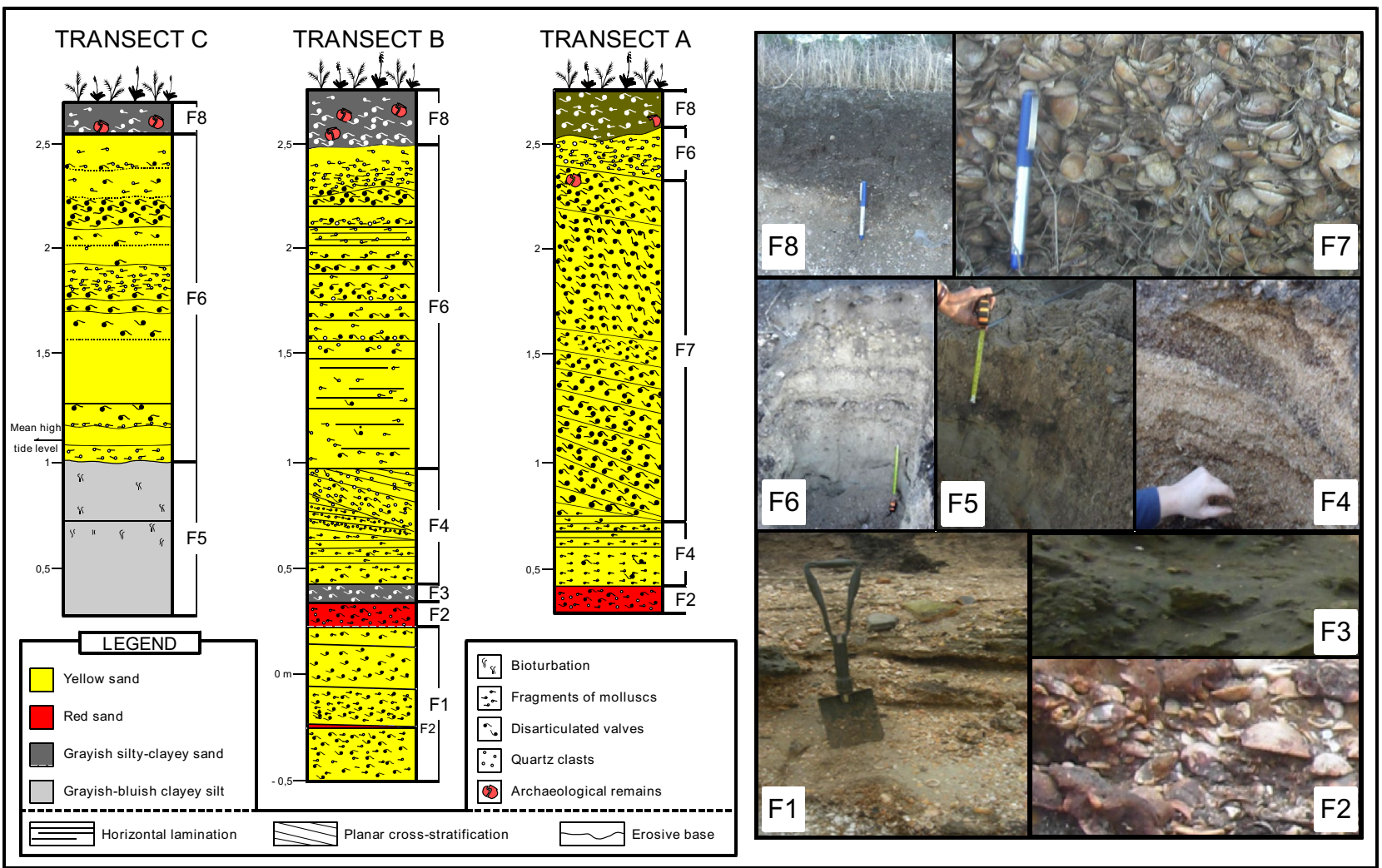

Fig. 2 Facies distribution, main sedimentary features and graphic detail of each of them

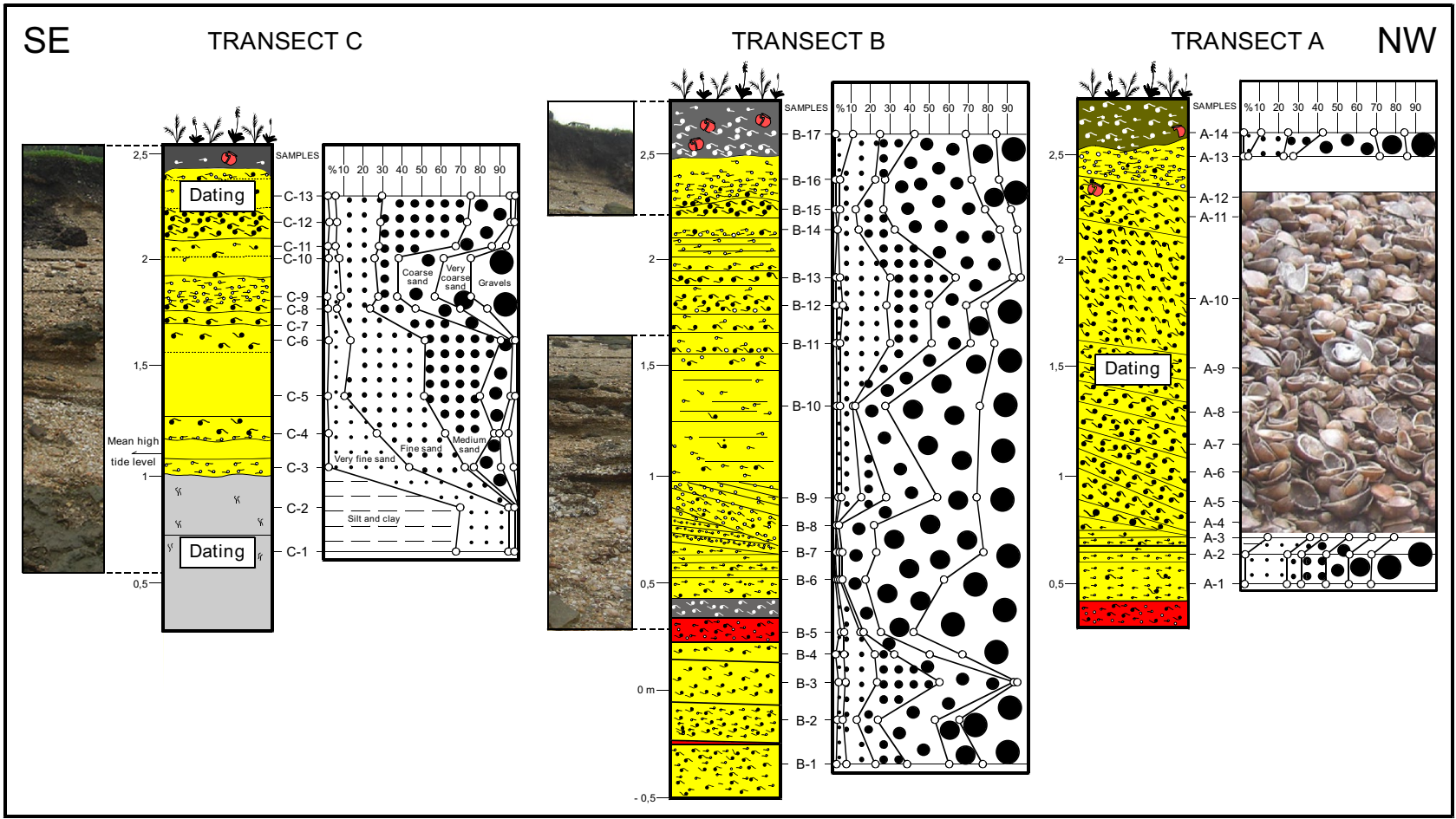

Fig. 3 Vertical distribution of samples and grain-size analysis of them 


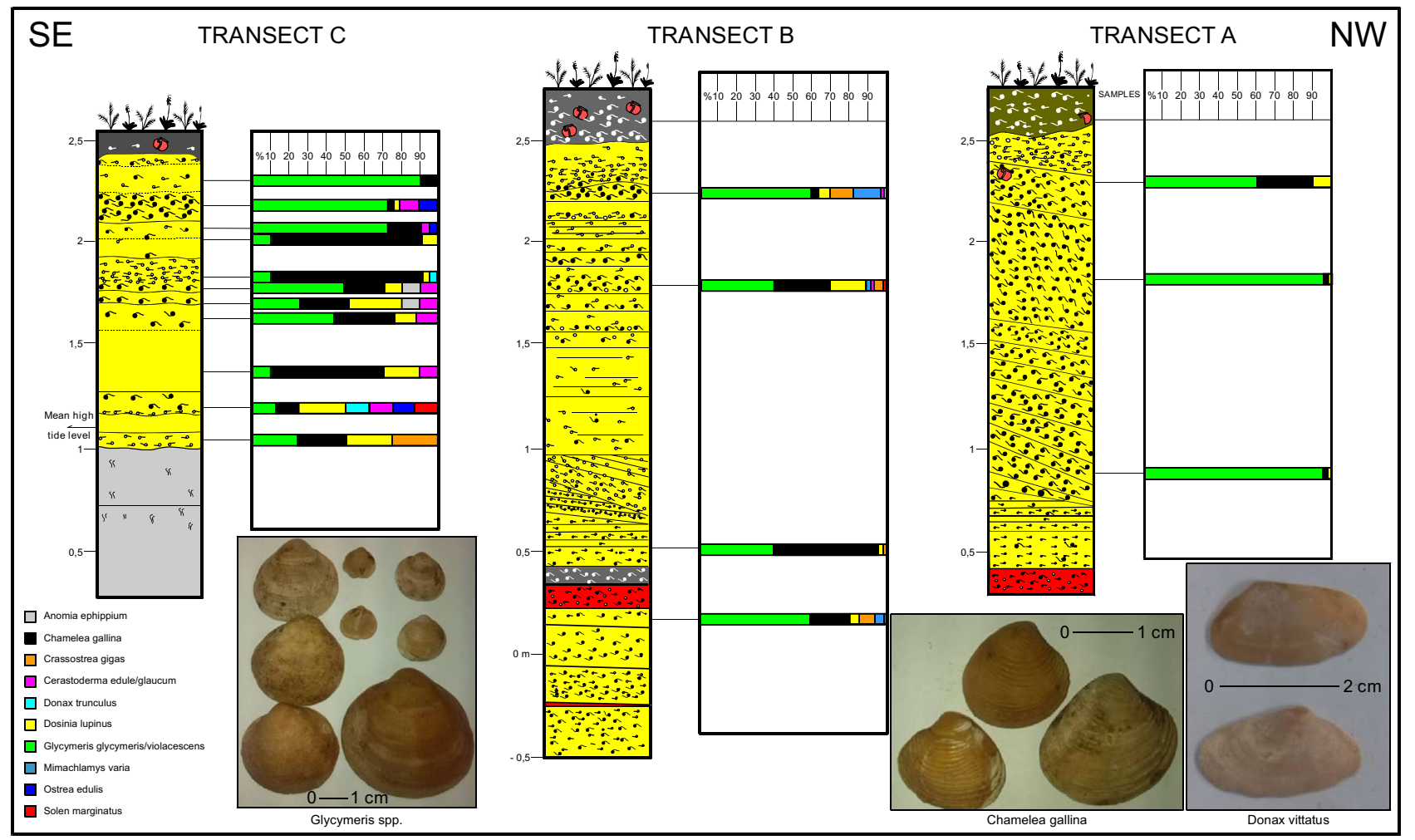

Fig. 4 Percentages of bivalves in selected samples and details of the main species

shell ( $\sim 30 \%$ by weight) was discarded by controlled acid etching $\left(0.5 \mathrm{M} \mathrm{HCl}\right.$ at $\left.25^{\circ} \mathrm{C}\right)$.

The ${ }^{14} \mathrm{C}$ method was applied by AMS to sample $\mathrm{C}-1$ at the Spanish National Centre for Accelerators (CNA), with the application of the reservoir effect correction $\left(-108 \pm 31{ }^{14} \mathrm{C}\right.$ yr) calculated by Martins and Soares (2013) in this area. This value was taken into account when using MARINE13 calibration curve (Reimer et al. 2013) for the conversion of conventional radiocarbon ages to calendar dates. Results are presented as calibrated ages for $2 \sigma$ intervals and BC/AD units (Table 2). This method was applied to samples collected in previous investigations carried out in the Tinto-Odiel estuary to obtain a general chronological evolution of this area (see Table 2 and Sect. 4.3).

In addition, the U/Th dating method was applied to samples A-9 and C-13, followed standard methods which are described by Van Calsteren and Thomas (2012). These datings were made at the laboratory of Applied Physics I of the University of Seville.

\section{Results and discussion}

\subsection{Sedimentary facies and interpretation}

Eight sedimentary facies have been differentiated (Fig. 2 and Table 1):

Facies 1 (Fl) This facies was observed exclusively in the intertidal zone of transect $\mathrm{B}$ ( $+0.5 \mathrm{~m}$ to $-0.5 \mathrm{~m}$ mslmean sea level-). It consists of yellow, coarse to medium sands (Figs. 2, 3) with frequent and well preserved gravelsized bioclasts (23-33\% weight in most samples). These coarse sediments present horizontal lamination or slightly inclined $\left(<10^{\circ}\right)$ to the north. This facies includes very thin layers (1-5 cm thickness) of red to dark muddy clays with reddish fragments of bilvaves and gastropods, very similar to facies 3 .

Bivalve shells are abundant (Fig. 4: Glycymeris glycymeris, Glycymeris violacescens, Chamelea gallina), whereas 


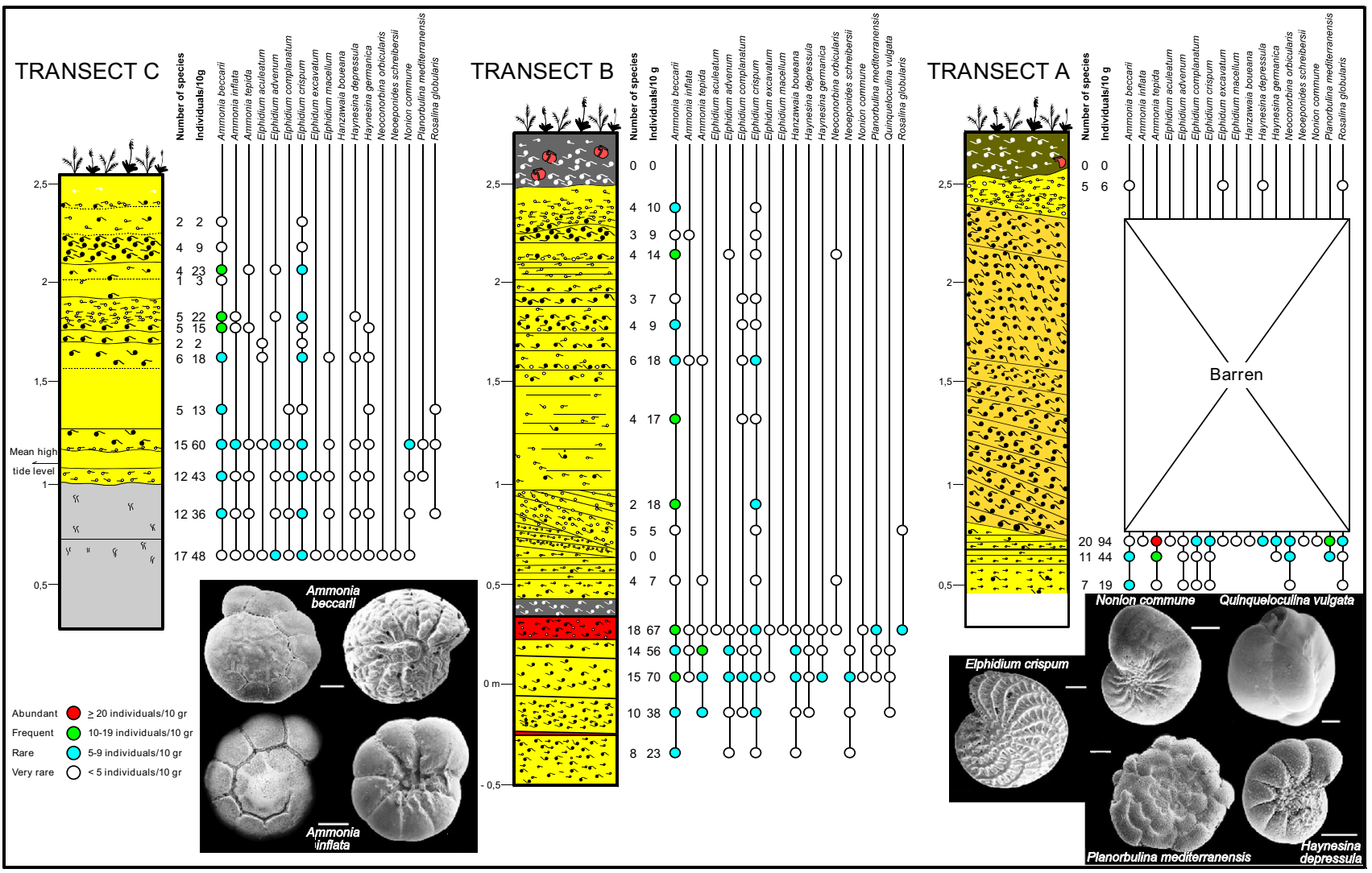

Fig. 5 Foraminifera: abundance, diversity and details of the main species

Table 2 Data base of ${ }^{14} \mathrm{C}$ and U/Th samples and results

\begin{tabular}{|c|c|c|c|c|c|c|c|c|}
\hline Sample code & Locality & Laboratory code & Figure 8 & ${ }^{14} \mathrm{C}$ age & Error & Calibrated age (U/Th) & $\begin{array}{l}\text { Median } \\
\text { probability } \\
\text { (AD) }\end{array}$ & References \\
\hline C-13 & $\begin{array}{l}\text { La Cascajera (Saltés } \\
\text { Island) }\end{array}$ & CNA-2821 & 9 & & & $(40 \mathrm{BC}-210 \mathrm{AD})$ & & This paper \\
\hline $\mathrm{C}-1$ & $\begin{array}{l}\text { La Cascajera (Saltés } \\
\text { Island) }\end{array}$ & CNA-2505 & 10 & 2100 & 35 & $30 \mathrm{AD}-265 \mathrm{AD}$ & 143 & This paper \\
\hline HU94-2 & $\begin{array}{l}\text { El Acebuchal (Saltés } \\
\text { Island) }\end{array}$ & UtC- $4185^{\mathrm{a}}$ & 11 & 1900 & 105 & $130 \mathrm{AD}-625 \mathrm{AD}$ & 374 & Dabrio et al. (2000) \\
\hline PU95-3 & Punta Umbría spit & GX-20909 & 12 & 1900 & 70 & $180 \mathrm{AD}-570 \mathrm{AD}$ & 376 & Goy et al. (1996) \\
\hline A-9 & $\begin{array}{l}\text { La Cascajera (Saltés } \\
\text { Island) }\end{array}$ & CNA-2818B & 13 & & & (370 AD-510 AD) & & This paper \\
\hline
\end{tabular}

Reservoir effect corrected $(-108 \pm 31$ years BP)

${ }^{\mathrm{a}} \mathrm{AMS}$ analysis

gastropods represent around 35-40\% of bioclasts. Shells of both groups are well preserved, with scarce evidences of bioerosion or abrasion. Foraminiferal diversity is moderate (8-14 species per sample) and density increases toward the top (up to 7 individuals per gram). The most abundant species are Ammonia beccarii, Ammonia tepida, Elphidum advenum, Elphidium complanatum, Elphidium crispum and Hanzawaia boueana (Fig. 5).

Interpretation This facies is interpretated as a shoal or a tidal sandy flat, with both bivalves and foraminiferal assemblages characteristic of very shallow marine environments, tidal flats and other intertidal areas of this estuary and the 
adjacent Huelva littoral (González-Regalado et al. 2001; Ruiz et al. 2004a; Gómez 2017). Taphonomical analysis of bivalves indicates a very limited transport or even the presence of an indigenous assemblage (Fernández López, 2000).

Facies 2 (F2): This unit was observed in trasects A and $\mathrm{B}$, at a fairly similar height in relation to the mean sea level (Fig. 2: +0.4 to $+0.2 \mathrm{~m}$ above $\mathrm{msl}$ ). This facies is very similar to F1, but it differs from it in the reddish color of both sands and bioclasts, as well as the higher percentages of the latter ( $>50 \%$ dry weight). These bioclasts have a variable mean grain size (1-5 cm in most cases), with numerous well-preserved, disarticulate valves of bivalves (Fig. 4: mainly G. glycymeris, Glycymeris violascecens and C. gallina). Foraminifera are well represented (18 species and 6.7 individuals per gram), with frequent specimens of $A$. beccarii, several species of Elphidium and some epiphytic species (Planorbulina mediterranensis and Rosalina globularis).

Interpretation The presence of reddish sands and bivalves is attributed to prolonged periods of subaerial exposure in a sandy tidal flat (F2), with oxidation of organic matter (Wiese, 2009). In this exposed environment and adjacent high-energy scenarios (e.g. F4-F6), the abundance of $A$. beccarii can be partially explained by the highly resistant shell of this species to energy agents (Cusminsky et al. 2006).

Facies 3 (F3): This facies is limited to transect B (+0.4 to $+0.3 \mathrm{~m}$ above $\mathrm{msl}$ ). This thin unit (Fig. $2: 9 \mathrm{~cm}$ thickness) differs from $\mathrm{F} 1$ in the finer grain size, with higher proportions of both silts and clays ( $>20 \%$ ). Macrofauna is dominated by bivalves, with G. glycymeris and G. violacescens as dominant species.

Interpretation The smallest mean grain size and the significant percentages of fine sediments would indicate a decrease in the enviromental energy. This facies could correspond to: 1) quieter areas located between higher areas of the sandy tidal plain (e.g. bioclastic sandy ridges) (De Vries 1963); or 2) meandering creeks or runnels, which migrate laterally across the sandy flats and may unite as tidal gullies before discharging into the main channels (Sherwood and Nelson, 1979).

Facies 4 (F4): This unit was disposed over F2 or F3 in transects A and B (Fig. 2: $+0.95 \mathrm{~m}$ to $+0.4 \mathrm{~m} \mathrm{msl}$ ). It consists of bioclastic, well-sorted very coarse sands and gravels with quartz conglomerates (Figs. 2, 3). This facies lie on the sandy flat sediments (F1) and presents an asymmetrical section, with a steeper face toward the NW. The internal structure shows a patent planar cross-stratification $\left(>30^{\circ}\right.$ in some beds), with a dominant ENE-WSW direction. Numerous internal erosion surfaces delimítate $<20 \mathrm{~cm}$ thick beds, massive or with inverse gradation in some cases. These erosion surfaces overlap bodies with similar inclination of their layers, which allows to deduce the overlapping of several bars.
Macrofauna is dominated by bivalves $(65 \%)$ and gastropods $(34 \%)$, with scarce individuals of scaphopods $(<1 \%)$. The most abundant species are the bivalves $C$. gallina and Glycymeris spp (Fig. 4), together with frequent specimens of the gastropods Calyptraea chinensis and Nassarius incrassatus. Most shells are fragmented and/or abraded, as well as they display considerable signs of bioerosion (Entobia, Caulostrepsis) and encrustation. Bivalves are frequently holed at the umbo and show frequent breaks of the valve margins, whereas numerous gastropods exhibit fractures of the last spire whorl and wear at the apex and the aperture.

Both diversity and density were higher in more proximal zones (transect A) compared to distal areas (transect B) (Fig. 5). In the former, both parameters increase from the basal, laminated levels to the upper, cross-stratified beds, with $A$. beccarii being replaced by A. tepida, Planorbulina mediterranensis, Rosalina globularis and several species of Elphidium and Haynesina. In contrast, foraminifera are scattered in transect B, with $A$. beccarii and E. crispum as the most representative species.

Interpretation The main features of this facies (general structure, internal disposition, biological content, taphonomy) are similar to those described in cheniers, interpreted as sedimentary shelly beach ridges deposited by waves during severe storms carrying the organic debris from the shallow shelf to the supratidal zone (Vilas and Arche, 1987; Dougherty and Dickson 2012).

Facies 5 (F5): This facies is limited to the high intertidal range of transect $\mathrm{C}$ (Fig. 2: $+1 \mathrm{~m}$ to $+0.5 \mathrm{~m} \mathrm{msl}$ ) and it dissapears towards the NW. It is characterized by massive grayish-bluish clayey silts ( silt + clay $>67 \%$ ) with abundant organic matter and frequent intercalations of very fine sands. Bioturbation is well developed, with numerous filled burrows produced by annelids. Macrofauna is represented by scattered valves of the bivalve $C$. gallina. The foraminiferal assemblages present a moderate diversity (Fig. 5: 12-17 species per sample) and density (36-48 individuals/10 g), with A. beccarii, Elphidium advenum and E. crispum as more representative species.

Interpretation The main features of this facies (grain size, bioturbation, macrofaunal content) are very similar to those observed in recent muddy tidal flats of Huelva estuary, protected from direct action of waves by spits or bioclastic ridges (cheniers, washover fans; Morales et al. 2014). In addition, the presence of abundant keeled forms of Elphidium and its co-occurrence with A. beccarii and other species of genus Ammonia is typical of these environments (Murray 2006; Hamed and Achyuthan 2011).

Facies 6 (F6). This facies is restricted to the supratidal zone (Fig. 2: +0.9 to $+2.5 \mathrm{~m} \mathrm{msl}$ ), being sumerged during the annual maximum tides. In a $\mathrm{N}-\mathrm{S}$ section, it presents a clear inclination to the north, with a steep avalanche face $\left(25^{\circ}-30^{\circ}\right)$ that reflects a clear lateral accretion and a 
progradational morphology. The internal structure is constituted by numerous beds of variable thickness $(5-30 \mathrm{~cm})$ composed of: (a) a lower bioclastic level characterized by an erosive, warped base covered by accumulations of bivalves (Glycymeris, Chamelea) and quartz conglomerates; and (b) a upper, sandy level that displays a diffuse horizontal lamination defined by a positive grain size gradation. Grain size decreases from transect B to transect C (Fig. 3) whereas the bed thickness increases in the same direction, indicating a proximality-distality relationship.

Macrofaunal content is slightly different between proximal (transect B) and distal (transect C) deposits. Gasteropods (Messalia varia, $C$. chinensis, $N$. incrassatus) are more abundant in the latter (40.5-42.5\%; mean: $41.75 \%)$ than in the former (34-40.4\%; mean: 37\%). In both transects, bivalves are dominant, with a higher diversity in the lower beds (Fig. 4: $+1 \mathrm{~m}$ to $+1.5 \mathrm{~m} \mathrm{msl}$ ), a codominance of Glycymeris spp and C. gallina in the intermediate deposits $(+1.5 \mathrm{~m}$ to $+2 \mathrm{~m} \mathrm{msl})$ and a predominance of Glycymeris spp. (>60\%) in the upper levels $(+2 \mathrm{~m}$ to $+2.5 \mathrm{~m} \mathrm{msl})$.

In F6, the samples consistently revealed between 2 and 23 total foraminiferal tests and $1-6$ species per $10 \mathrm{~g}$ of sediment, except in transect $\mathrm{C}$, near the mean high tide level (Fig. 5: 12-15 species; 43-60 individuals per $10 \mathrm{~g}$ ). In this facies, the A. beccarii-E. crispum assemblage represents $62.2 \%$ of all tests, with percentages up to $75 \%$ in most samples. Different evidences observed in the foraminiferal tests of these robust species (breaking of the last chambers, abrasion of the external ornamentation, loss of the keel) suggest an important transport process.

Interpretation This facies is interpreted as a set of washover fans, with vertical aggradation and progradation to the north. These deposits would come from the storm erosion of cheniers and adjacent coastal areas, such as tidal flats, barrier islands, beaches and shallow coastal areas (Hudock et al. 2014; Morales et al. 2014). The biological content suggests a tidal flat/infralittoral origin for the basal sediments of transect $\mathrm{C}$, with high diversity in both macrofauna and microfauna, whereas a beach/chenier origin is inferred for the upper layers, with low diversity and an increasing abundance of Glycymeris. At present, this genus is common in these environments along the Huelva littoral, as inhabitant of shallow marine sandy bottoms ( $<50 \mathrm{~m}$ depth; FAO 2016; Gómez 2017).

Facies 7 (F7): This facies was only present in transect $\mathrm{A}(+0.7 \mathrm{~m}$ to $+2.3 \mathrm{~m} \mathrm{msl})$. This unit is characterized by a dense accumulation of desarticulated bivalve shells included in a sparse clayey matrix $(<10 \%$ dry weight) alternating with very fine clayey layers $(<2 \mathrm{~cm}$ thickness). The internal structure of the former is composed of numerous thin, bioclastic-supported beds (5-25 cm thickness) with a sharp erosional base inclined in SE-NW direction and covered by imbricated bivalve shells.
Macrofauna is dominated by bivalves (mean $57.5 \%$ ) and gastropods (mean $42 \%$ ). G. violacescens make up $85 \%$ of the bivalves (Fig. 4) and contributes up than $50 \%$ to the total dry weight. Large (diameter $>5 \mathrm{~cm}$ ), convex-side-up shells of this species dominate the spectrum (Fig. 4), with Dosinia lupinus and C. gallina as very secondary species. In this facies, shells are low to moderately abraded, with frequent holes at the umbo and breakings of the valve margins. This facies was barren of foraminifera.

The archaeological record is very sparse. Only ceramic fragments and some remains of amphorae have been found.

Interpretation This deposit would correspond to the human exploitation of bivalves, probably for the elaboration of mixed sauces of fish (Bermejo et al. 2016). The absence of foraminifera and other microfaunal groups is characteristic of cultural middens (Carter 1999) and the almost monospecific accumulation of Glycymeris, an edible genus, is usual in archaeological sites of Europe and Asia (Light 2017).

Facies 8 (F8): The uppermost part of all transects $(\geq 2.5 \mathrm{~m} \mathrm{msl})$ consists of an edaphic, organic-rich horizon (Fig. 2: 25-30 cm thickness) composed of black to brownish fine to medium sands. This level contains frequent shells of bivalves (G. glycymeris, G. violacescens, C. gallina) and gastropods (Bolinus brandaris, Hexaplex trunculus), which appear in numerous concentrations along this horizon. This facies was barren of foraminifera.

Molluscs show no evidence of transport or abrasion but some of them present evidences of human manipulation. In bivalves, the clearest signs of food use are some acute breakings of the ventral margin (Fig. 6a), whereas gastropods are crushed by progressively breaking off larger segments of the shell (Fig. 6b).

This edaphic facies includes numerous fragments of amphorae and pottery (Fig. 6c). The majority of amphorae are grouped into three main types: African III/Keay 25 X, LRA1 and Keay XIXC. This unit contains a large and varied building material, with pedalis, semipedalis, tegulae and imbrices. In addition, human bone remains and part of a pillar have been found (Fig. 6d).

Interpretation The biological content, its taphonomic characteristics and the archaeological remains are typical of a cetaria, a salting factory that processed molluscs (Campos et al. 2015). Some of them present higher food quality, e.g. C. gallina, whereas others have less commercial and gastronomic values, e.g. Glycymeris spp. (Stiner 1999; Light 2017).

On the other hand, the gastropods Hexaplex trunculus and Bolinus brandaris were used in dyeing 'purpleblue'. The hypobranquial gland of both species produces a whiteish secretion that results in purple colorants, under the successive action of an enzyme, oxygen and light (Elsner 1992). 


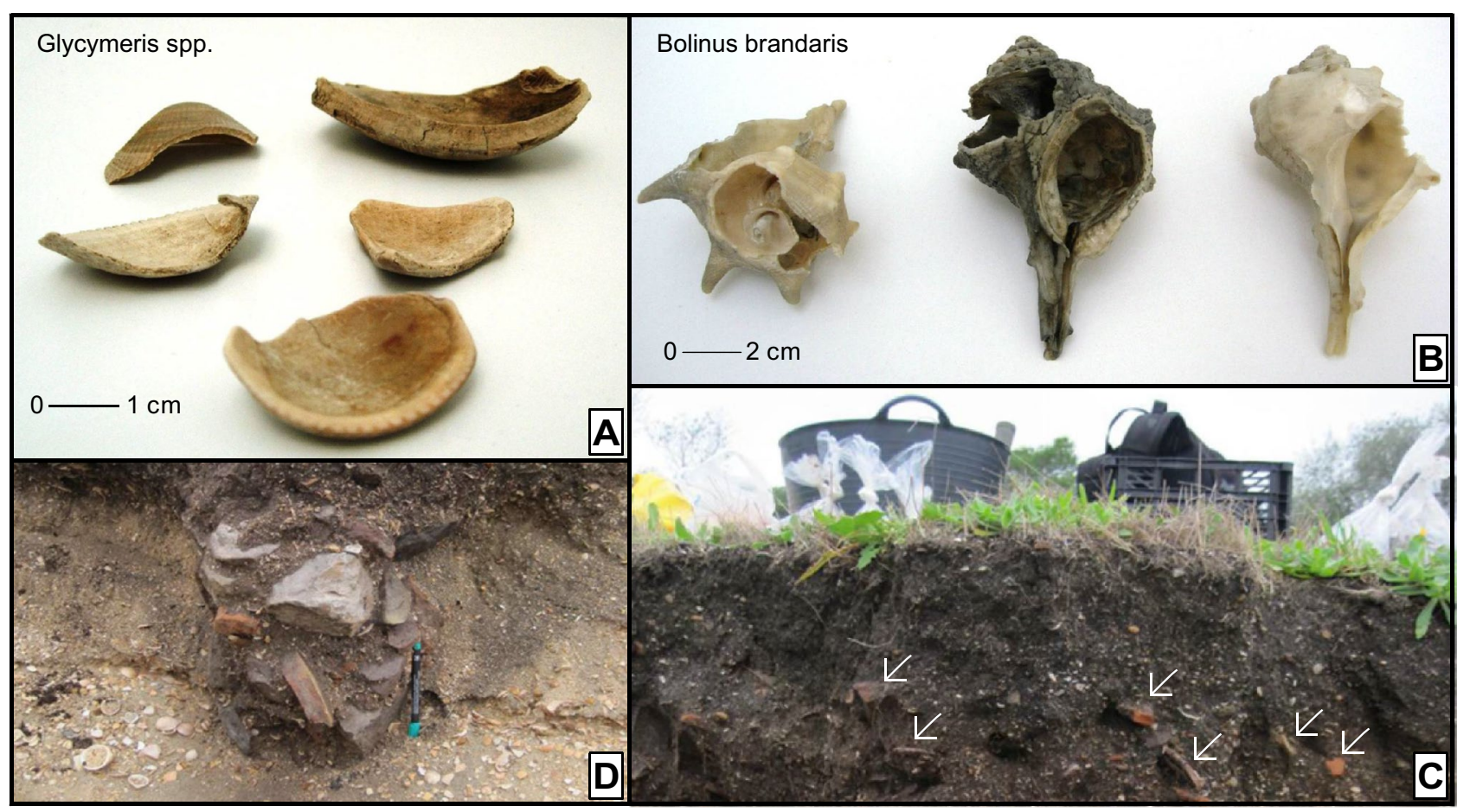

Fig. 6 Evidence of a Roman cetaria. a Glycymeris spp. with evidence of human manipulation at the ventral margin; b specimens of Bolinus brandaris with rupture of the whorl; $\mathbf{c}$ fragments of amphorae and pottery (F8); $\mathbf{d}$ remains of a pillar

\subsection{Chronology}

Radiocarbon chronology and U/Th datings provide an approximation on the age of the material studied (Table 2). Two samples (C-1 and C-13) place the deposit of most materials between 40 cal. yr BC and 265 cal. yr AD, whereas the age of F7 is later (370 cal. yr AD-510 cal. yr AD).

Additional chronological data can be obtained from the archaeological content of the upper edaphic horizon. Remains of pottery and amphorae permit to infer a human activity from the end of the 4th century AD until the end of the 5th century AD (Campos et al. 2015).

\subsection{Palaeoenvironmental evolution of La Cascajera}

Three phases may be separated in the palaeoenvironmental evolution of La Cascajera, according to the facies distribution and their chronology (Fig. 7).

\subsubsection{Phase 1 (>40 cal. yr BC)}

The lower limit of this phase (e.g. the lower boundary of F1) is not observed in the transects studied, whereas the upper limit coincides with the upper boundary of F5. At a first stage (transect B), this area was occupied by a partially exposed sandy flat or sand shoal (Fig. 7a: F1), with occasional periods of prolonged aerial exposure that would lead to the fine intercalations of F2. The overlying, reddish sediments of $\mathrm{F} 2$ (Fig. $7 \mathrm{~b}$ : transects $\mathrm{A}$ and $\mathrm{B}$ ) reflect a temporary emersion of this sector that ends with the appearance of new intertidal bodies, deposited on quieter areas or creeks (F3) of a tidal flat (Fig. 7b: transect B).

In this intertidal scenario, these basal deposits are covered by a chenier (F4) in transects A and B (Fig. 7c). In contrast to other chenier plains, Morales et al. (2014) have shown that the development of cheniers on Saltés Island is linked mainly to high spring tides during the last 200 years, although storms can also act as agents that originate them. In this area, winter storms originate new beach ridges with a periodicity of 6 and 9-10 years (RodríguezRamírez et al. 2003) and consequently they can also lead to the appearance of cheniers.

The third step of this phase is the implantation of a muddy tidal flat toward the southeast (Fig. 7d: F5). This change could be linked to: (a) the appearance of new cheniers and the presence of low-energy areas (e.g. mudflats) between them, as in other chenier plains (McBride et al. 2007); or (b) changes in the general dynamics of the estuary due to the progradation of the Punta Umbria spit that would protect inner, muddy tidal flats and marshes (see Sect. 4.4). 


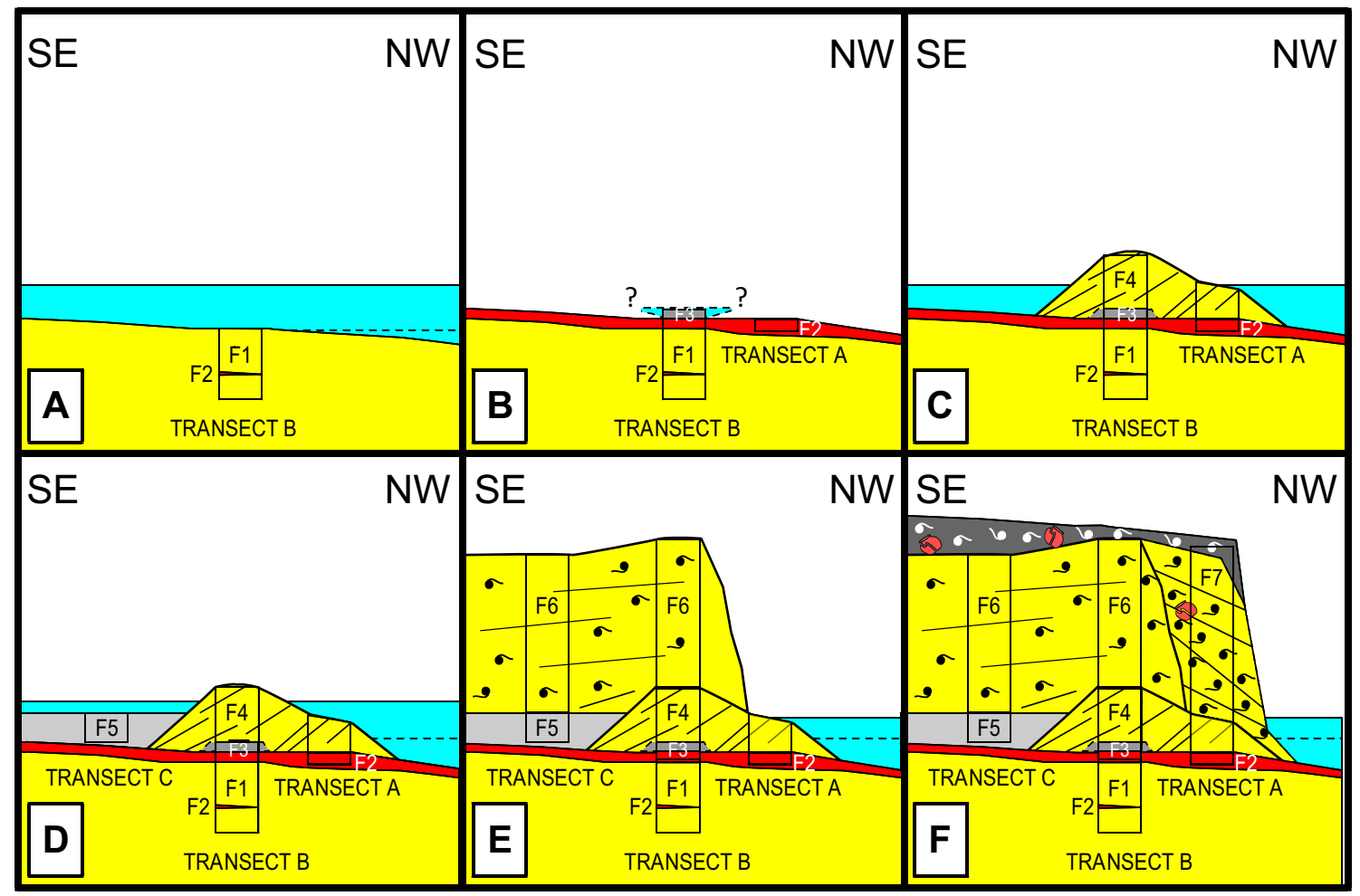

Fig. 7 a-f Geological evolution of the northern part of La Cascajera

\subsubsection{Phase 2 ( 40 cal. yr BC -260 cal. yr AD)}

This second phase is characterized by the deposit of washover fans (Fig. 7, e) on cheniers (transect B) or mudflats (transect C). These deposits (F6) can be distinguished from the anthropogenic shell middens (F7) in their internal stratigraphic structure, as well as by the greater diversity of mollusks and foraminifera. Middens usually show an absence of foraminifera or an extremely low diversity compared to cheniers or washover fans (Sullivan and O'Connor 1993; Lilley et al. 1999).

The origin of washover fans is usually linked to highenergy events, such as extreme weather events (storms, hurricanes) or tsunamis (e.g. Deery and Howard 1977; Shaw et al. 2015). In this period (1st century BC-3th century $\mathrm{AD})$, several tsunamis desolated this region, with an associated sedimentary record of cheniers, shelly beds or erosive surfaces both in the Tinto-Odiel and Guadalquivir estuaries (González-Regalado et al. 2013), with destruction of salted fish factories (Campos et al. 2015).

\subsubsection{Phase 3 ( 260 cal. yr AD-500 cal. yr AD)}

The final scenario of this local evolution is defined by the construction and development of a fish salting factory during Roman times (4th century AD-5th century AD) in this northern part of La Cascajera, located on top of washover fan deposits (Fig. 7, f). Consequently, this area was definitely emerged during this historic period.

Evidence of industrial activities (amphorae, building materials, pottery, sinks) have been found in the surface edaphic horizon of all transects (F8) and other adjacent areas (Bedia, 2008), within an archaeological site that extends along six hectares to the east. An additional evidence of this human activity is the thick, almost monospecific accumulation of Glycymeris valves observed in transect A (see Figs. 2, 4: F7), with an age similar to that deduced for the salting factory (Table 1: 4th-5th centuries $\mathrm{AD}$ ). This accumulation could have been subjected to wave action later, which would explain the imbrication of disarticulated valves observed in this transect. This mixture of processes has also been suggested for other accumulations of this species in different archaeological sites of southwestern Spain (Bernáldez et al. 2010).

This cetaria would be dedicated: (a) to obtaining purple from some gastropods (Hexaplex, Bolinus); (b) the meat use of edible bivalves (mainly Glycymeris); and (c) the preparation of fish sauces (Campos et al. 2015). Similar productions have been deduced from the analysis of other nearby Roman factories in southwestern Spain (Campos et al. 2002). 
Fig. 8 a, b Location of some of the main Roman cetariae in the southwestern Spanish littoral; c palaeoenvironmental reconstruction of Saltés Island and the adjacent areas around 4th-5th centuries $\mathrm{AD}$

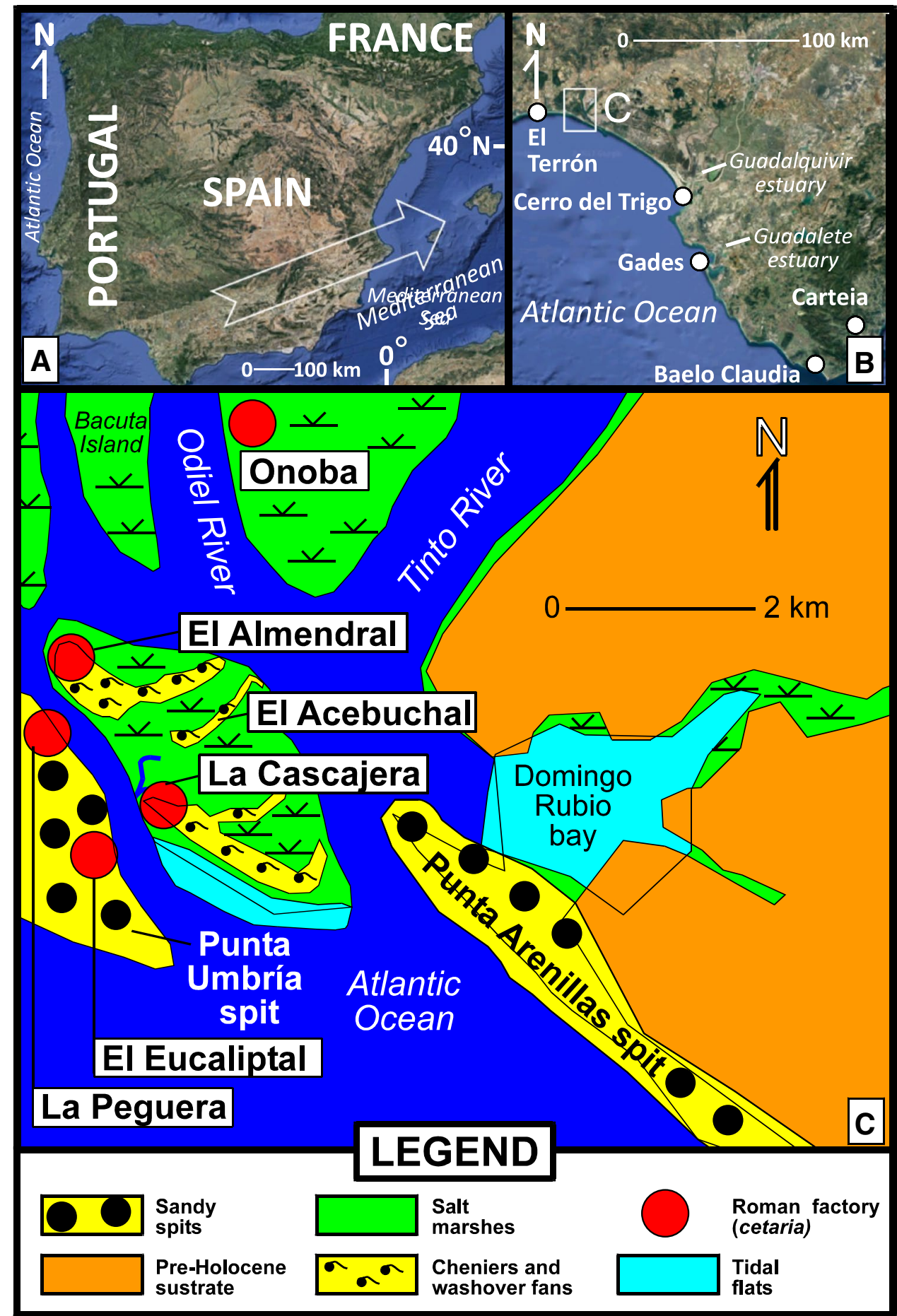

\subsection{Palaeoenvironmental reconstruction of Tinto-Odiel river mouth during the Roman period}

Additional data obtained from other geological researchs around Saltés Island permit to draw a palaeoenvironmental evolution of this area during the Roman period (Fig. 8). Between $100 \mathrm{yr} \mathrm{BC}$ and $300 \mathrm{yr} \mathrm{AD}$, the main geological feature is a major progradation in the sandy spits of Punta Umbría and Punta Arenillas (stage $\mathrm{H}_{3}$ of Dabrio et al. 2000). At the entrance of the estuary, both the growth of Punta Umbría spit and the high spring tides caused the emersión of new sandy ridges and the appearance of washover fans in the northern part of La Cascajera on previous tidal flats (see Sect. 4.3 and Table 2). This growth allowed the establishment of several Roman salting factories in 
this period in this area during these centuries (Fig. 8c: El Eucaliptal, La Peguera). In the eastern area, the Punta Arenillas spit partially closed the entrance to the Domingo Rubio tidal channel (Dabrio et al. 2000) and the decreasing tidal energy favoured a rapid filling of this channel (Pendón et al. 1998).

The 4th century AD probably witnessed a new growth of Punta Umbría spit (Table 2: 180 yr AD-570 yr AD; mean probability $376 \mathrm{yr} \mathrm{AD}$ ) and consequently the internal areas of the estuary were more protected from the action of tides and waves. The migration and stabilization of new cheniers caused the emersión of new prograding sandy ridges in Saltés Island, such as El Acebuchal (Table 2: 130 yr AD-625 yr AD; mean probability 374 yr AD; see Fig. 1c for location), located between two ridges previously emerged (El Almendral and La Cascajera).

In a later phase, the stabilization of La Cascajera above the mean tidal level propitiated the construction of a new cetaria on previous washover fans and cheniers. This fish salting factory was the last one built in Roman times in this area. The dismemberment of the Roman Empire and these invasions brought about the end of this prosperity in the 7th century AD.

\section{Conclusions}

During Roman times (1st century BC-5th century AD), the palaeoenvironmental evolution of Saltés Island (TintoOdiel estuary, SW Spain) developed in a regressive scenario, with the transition from shallow marine environments (e.g. tidal flats) to progressively emerged deposits (cheniers). Washover fans derived from high-energy events (1 st century BC-3th century AD) were arranged over these cheniers and were used for the installation of a Roman salting factory some two or three hundred years later. The paleontological analysis of the middens associated with their activity clearly differentiates them from other biogenic concentrations, with a monospecific concentration of Glycymeris with clear signs of food use, as well as the absence of benthic foraminifera, among other distinctive features.

Acknowledgements This work has been carried out through the projects 'Roman cities of the Baetica. CORPVS VRBIVM BAETICARVM (I) (CUB)' (Andalusian Government) and 'The cultural and natural heritage in the Marismas del Odiel Biosphere Reserve (Huelva) and its interaction with the territory and society' (Campus of International Excellence in Heritage PatrimoniUM 10). Other funds have come from Andalusian Government (groups HUM-132, RNM-238 and RNM-293). It is a contribution to the Research Centre in Historical, Cultural and Natural Heritage (CIPHCN) of the University of Huelva. We would like also to thanks Dr. Ana Bernabeu and three anonymous reviewers for their useful comments and suggestions.

\section{References}

Alonso, C., Gracia, F. J., Del Río, L., Anfuso, G., Benavente, J., \& Martínez, J. A. (2004). Registro morfosedimentario de eventos históricos de alta energía en el litoral Atlántico del Estrecho de Gibraltar (Trafalgar-Tarifa). In G. Benito \& A. Díez (Eds.), Contribuciones recientes sobre Geomorfología (pp. 263-272). Madrid: SEG-CSIC.

Alonso, C., Gracia, F. J., Rodríguez-Polo, S., \& Martín Puertas, C. (2015). El registro de eventos energéticos marinos en la bahía de Cádiz durante épocas históricas. Cuaternario y Geomorfología, 29, 95-117.

Álvarez-Fernández, E. (2015). Continuity of human-marine fauna interaction during the Holocene in Cantabrian Spain. Quaternary International, 364, 188-195.

AMA (1993) (Agencia de Medio Ambiente). Plan de policia de aguas de1 litoral andaluz. Junta de Andalucia (unpublished report).

Bedia, J. (2008). Los siglos oscuros: de Tartessos a la Edad Media. Huelva Arqueológica, 21, 55-84.

Bermejo, J., Campos, J.M., García, J.M. \& Vera, J.C. (2016). Arqueología en el paraje natural de Marismas del Odiel (Huelva) y su entorno, desde la Prehistoria hasta la época tardoantígua. N: Campos, J. M. (ed.), El patrimonio histórico y cultural en el paraje natural Marismas del Odiel: un enfoque diacrónico y transdisciplinar. Huelva: Universidad de Huelva, pp. 107-129.

Bernáldez, E., García-Viñas, E., Pozo, C., Lozano, M. C., \& Vera, J. L. (2010). Inferencias bioestratinómicas en la interpretación arqueológica de yacimientos del Holoceno. Férvedes, 6, 85-94.

Bonsor, G. (1928). Tartessos. Excavaciones del Cerro del Trigo (despoblado romano en el coto de Doñana, Almonte). Junta Superior de Excavaciones y Antigüedades, 97.

Borja, F., Zazo, C., Dabrio, C. J., Díaz del Olmo, F., Goy, J. L., \& Larío, J. (1999). Holocene aeolian phases and human settlements along the Atlantic coast of southern Spain. The Holocene, 9, 333-339.

Borrego, J., Morales, J. A., \& Pendón, J. G. (1993). Holocene filling of an estuarine lagoon along the mesotidal coast of Huelva: The Piedras River mouth, southwestern Spain. Journal of Coastal Research, 9, 242-254.

Borrego, J., Ruiz, F., González-Regalado, M. L., Pendón, J. G., \& Morales, J. A. (1999). The Holocene transgression into the estuarine central basin of the Odiel River mouth (Cadiz gulf, SW, Spain): Lithology and faunal assemblages. Quaternary Science Reviews, 18, 769-788.

Camacho, S., Boski, T., Moura, D., Scott, D., Connor, S., \& Pereira, L. (2017). Paleoenvironmental evolution of the Guadiana Estuary, Portugal, during the Holocene: A modern foraminifera analog approach. The Holocene, 27, 197-235.

Campos, J.M. (2011). Onoba Aestuaria. Una ciudad portuaria en los confines de la Bética. Ed. Ayuntamiento de Huelva, Huelva.

Campos, J.M., Alzaga, M., Benabat, Y., Bora, F., Bermúdez, T., Cuenca, J.M., et al. (1997). Factoría de salazones de El Eucaliptal (Punta Umbría, Huelva). In Anuario Arqueológico de Andalucía 1993, vol. III, pp. 313-323.

Campos, J. M., Bermejo, J., \& Rodríguez-Vidal, J. (2015). La ocupación del litoral onubense en época romana y su relación con eventos de alta energía. Cuaternario y Geomorfología, 29, 75-93.

Campos, J.M. \& Gómez, F. (2001). La Tierra llana de Huelva: Arqueología y Evolución del paisaje. Arqueología Monografías, 13. Ed. Consejería de Cultura Junta de Andalucía, Sevilla.

Campos, J. M., Pérez Macías, J. A., Vidal, N., \& Gómez, A. (2002). Las industrias de salazones del litoral onubense: Los casos de "El Eucaliptal" (Punta Umbría) y "El Cerro del Trigo" (Doñana, Almonte). Huelva en su historia, 9, 77-96. 
Campos, J. M., Pérez, J. A., \& Vidal, N. (1999a). El Eucaliptal, una necropolis romana de Pescadores (Punta Umbría, Huelva). Huelva en su Historia, 7, 195-231.

Campos, J.M., Pérez, J.A. \& Vidal, N.O. (1999b). Las cetariae del litoral onubense en época romana. Ed. Servicio de Publicaciones de la Universidad de Huelva.

Carretero, M. I., Ruiz, F., Pozo, M., Rodríguez Vidal, J., Muñoz Pichardo, J. M., Cáceres, L. M., et al. (2011). Trace Elements in Holocene sediments of the southern Doñana National Park (SW Spain): Historical pollution and applications. Environmental Earth Sciences, 64, 1215-1223.

Carretero, M. I., Ruiz, F., Rodríguez-Ramírez, A., Cáceres, L. M., Rodríguez-Vidal, J., \& González-Regalado, M. L. (2002). The use of clay minerals and microfossils in palaeoenvironmental reconstructions: The Holocene littoral strand of Las Nuevas (Doñana National Park, SW Spain). Clay Minerals, 37, 93-103.

Carter, M. (1999). Chenier and shell midden: An investigation of cultural and natural shell deposits at Rodds Peninsula, Central Queensland Coast. Australian Archaeology, 48, 56.

Cearreta, A. (2017). Holocene sea-level change in the Bilbao Estuary (North Spain): Foraminiferal Evidence. Micropaleontology, 44, 265-276.

Cearreta, A., Benito, X., Ibáñez, C., Trobajo, R., \& Giosan, L. (2016). Holocene palaeoenvironmental evolution of the Ebro Delta (Western Mediterranean Sea): Evidence for an early construction based on the benthic foraminiferal record. The Holocene, 26, 1438-1456.

Cusminsky, G., Martínez, D., \& Bernasconi, E. (2006). Foraminíferos y ostrácodos de sedimentos recientes del estuario de Bahía Blanca, Argentina. Revista Española de Micropaleontología, 38, 395-410.

Dabrio, C. J., Zazo, C., Goy, J. L., Sierro, F. J., Borja, F., Lario, J., et al. (2000). Depositional history of estuarine infill during the last postglacial transgression (Gulf of Cadiz, Southern Spain). Marine Geology, 162, 381-404.

Dabrio, C. J., Zazo, C., Lario, J., Goy, J. L., Sierro, F. J., Borja, F., et al. (1999). Sequence stratigraphy of Holocene incised valley fills and coastal evolution in the Gulf of Cádiz (southern Spain). Geologie in Mijnbouw, 77, 23-281.

De Vries, G. (1963). Bay of Fundy intertidal sediments. Journal of Sedimentary Petrology, 33, 844-854.

DeBritto, B. (1609). Segunda parte da Monarchia Lusytana. Pedro Crasbeek, Lisbon.

Deery, J. R., \& Howard, J. D. (1977). Origin and character of washover fans on the Georgia Coast, USA. Gulf Coast Association of Geological Societies Transactions, 27, 259-271.

Dougherty, A. J., \& Dickson, M. E. (2012). Sea level and storm control on the evolution of a chenier plain, Firth of Thames, New Zealand. Marine Geology, 307-310, 58-72.

Ejarque, A., Juliá, R., Mesquita, F., Marco, J., \& Riera, S. (2016). Coastal evolution in a Mediterranean Microtidal Zone: Mid to Late Holocene natural dynamics and human management of the Castelló lagoon, NE Spain. PLoS One, 11, e0155446.

Elsner, O. (1992). Solution to the enigmas of dyeing Tyrian purple and the biblical tekhelet. Dyes in History and Archaeology, 10, 11-16.

Estiarte, M., Peñuelas, J., López-Martínez, C., \& Pérez-Obiol, R. (2008). Holocene palaeoenvironment in a former coastal lagoon of the arid south eastern Iberian Peninsula: Salinization effects on $\delta^{15} \mathrm{~N}$. Vegetation History and Archaeobotany, 17, 667-674.

FAO (2016). The living marine resources of the Eastern Central Atlantic. In Volume 2. Bivalves, gastropods, hagfishes, sharks, batoid fishes and chimaeras. Food and Agriculture Organization of the United Nations, Rome.

Fernández López, S. (2000). Temas de Tafonomía. Servicio de Publicaciones (p. 167). España: Universidad Complutense de Madrid.

Figueroa, M.E. \& Clemente, L. (1979). Dinámica geomorfológica de los estuarios de los ríos Tinto y Odiel (Huelva). Aplicaciones a la ordenación del territorio. IV Reunión Nacional para el estudio del Cuaternario, Bañolas, pp. 115-129.

Gacio, H. \& Sayago, J.M. (2011). Guía de las aves del Paraje Natural Marismas del Odiel (Huelva). Ed. Algakon, Ocio Servicios y Producciones.

García Antón, M., Gil, G., Pagés, J. L., \& Alonso, A. (2006). The Holocene pollen record in the Villaviciosa Estuary (Asturias, North Spain). Palaeogeography, Palaeoclimatology, Palaeoecology, 237, 280-292.

García-Escárzaga, A., Gutiérrez-Zugasti, I., González-Morales, M. R., \& Cobo-García, A. (2017). Shells and humans: Molluscs and other coastal resources from the earliest human occupations at the Mesolithic Shell Midden of El Mazo (Asturias, Northern Spain). Papers from the Institute of Archaeology, 27, 1-17.

Gómez, G. (2017). Guía de los moluscos marinos de Huelva y del Golfo de Cádiz (p. 214). Diputación Provincial de Huelva: Servicio de Publicaciones.

González-Regalado, M. L., Borrego, J., Abad, M., Ruiz, F., Carro, B., Rodríguez Vidal, J., et al. (2013). Geological evidences of prehistorical and historical tsunamis in a tidal channel of southwestern Spain. In B. Singh Klotia (Ed.), Holocene: Perspectives, environmental dynamics and impact events (pp. 101-109). New York: Nova Science Publishers.

González-Regalado, M. L., Ruiz, F., Baceta, J. I., González-Regalado, E., \& Muñoz, J. M. (2001). Total benthic foraminifera assemblages in the southwestern Spanish estuarios. Geobios, 34, 39-51.

Goy, J. L., Zazo, C., Dabrio, C. J., Lario, J., Borja, F., Sierro, F. J., et al. (1996). Global and regional factors controlling changes of coastlines in southern Iberia (Spain) during the Holocene. Quaternary Science Reviews, 15, 773-780.

Guerra, L., Veiga-Pires, C., Ruiz, F., \& Abad, M. (2014). A synthesis of Doñana National Park (Spain) Late Holocene history: Palaeoenvironmental evolution, climate influence, high energy events and foraminifera records. Comunicacoes Geológicas, 101, 1461-1465.

Gutiérrez-Más, J. M. (2011). Glycymeris shell accumulations as indicators of recent sea-level changes and high-energy events in Cádiz Bay (SW Spain). Estuarine, Coastal and Shelf Science, 92, 546-554.

Gutiérrez-Mas, J. M., Juan, C., \& Morales, J. A. (2009). Evidence of high-energy events in shelly layers interbedded in coastal Holocene sands in Cadiz Bay (south-west Spain). Earth Surface Processes and Landforms, 34, 810-823.

Gutiérrez-Zugasti, I. (2017). The shell midden of Pico Ramos and the exploitation of molluscs in the Cantabrian region (northern Spain). In L. Zapata (Ed.), Humans on the Basque coast during the 6th and 5th millenium B.C. The shell midden of Pico Ramos (Muskiz, Bizkaia) (pp. 53-57). Bilbao: Trrres.

Hamed, A., \& Achyuthan, H. (2011). Benthic foraminiferal assemblages from the estuary and tidal zones along the east coast of Tamilnadu, India: Deciphering Holocene sea-level change. Journal of the Palaeontological Society of India, 56, 195-200.

Hudock, J. W., Flaig, P. P., \& Wood, L. J. (2014). Washover fans: A modern geomorphologic analysis and proposed classification scheme to improve reservoir models. Journal of Sedimentary Research, 84, 854-865.

IEO (1992) (Instituto Español de Oceanografía). Variation espaciotemporal de parámetros físico-químicos y biologicos en la ria de Huelva y área de influencia, en el periodo 1987-1991. Internal report no. 138.

Junta de Andalucía. (1991). Estudio de la gestión integrada de las marismas del Odiel. Junta de Andalucía: Agencia de Medio Ambiente.

Lario, J., Zazo, C., Dabrio, C. J., Somoza, L., Goy, J. L., Bardají, T., et al. (1995). Record of recent Holocene Sediment input on spit bars and deltas of South Spain. Journal of Coastal Research, 17, 241-245. 
Leorri, E., \& Cearreta, A. (2004). Holocene environmental development of the Bilbao estuary, northern Spain: Sequence stratigraphy and foraminiferal interpretation. Marine Micropaleontology, 51, $75-94$.

Light, J. (2017). Marine shell artefacts: Cautionary tales of natural wear and tear as compared to resourceful anthropogenic modification processes. In M. J. Allen (Ed.), Molluscs in archaeology: Methods, approaches and applications (pp. 342-361). Oxford: Oxbow Books.

Lilley, I., Brian, D., \& Ulm, S. (1999). The use of foraminifera in the identification and analysis of marine shell middens: A view from Australia. In M. J. Mountain \& D. Bowdery (Eds.), Taphonomy: The analysis of processes from Phytoliths to Megafauna, research School of Pacific and Asian Studies (pp. 9-16). Canberra: Australian National University.

Luque, L., Lario, J., Civis, J., Zazo, C., Goy, J. L., \& Dabrio, C. J. (2002). Sedimentary record of a tsunami during Roman times, Bay of Cadiz, Spain. Journal of Quaternary Science, 17, 623-631.

Martins, J. M. M., \& Soares, A. M. M. (2013). Marine radiocarbon reservoir effect in Southern Atlantic Iberian coast. Radiocarbon, $55,1123-1134$.

McBride, R. A., Taylor, M. J., \& Byrnes, M. R. (2007). Coastal morphodynamics and Chenier-Plain evolution in southwestern Louisiana, USA: A geomorphic model. Geomorphology, 88, 367-422.

Morales, J. A., Borrego, J., \& Ballesta, M. (2004). Influence of harbour constructions on morphosedimentary changes in the Tinto-Odiel estuary mouth (south-west Spain). Environmental Geology, 46, 151-164.

Morales, J. A., Borrego, J., \& Davies, R. A. (2014). A new mechanism for chenier development and a facies model of the Saltés Island chenier plain (SW Spain). Geomorphology, 204, 265-276.

Murray, J. (2006). Ecology and applications of benthic foraminifera (p. 426). New York: Cambridge Press.

Nocete, F., Álex, E., Nieto, J. M., Sáez, R., \& Bayorna, M. R. (2005). An archaeological approach to regional environmental pollution in the south-western Iberian Peninsula related to Third millennium BC mining and metallurgy. Journal of Archaeological Science, 32, 1566-1576.

Pascual, A., Rodríguez-Lázaro, J., Weber, O., \& Jouanneau, J. M. (2002). Late Holocene pollution in the Gernika estuary (southern Bay of Biscay) evidenced by the study of Foraminifera and Ostracoda. Hydrobiologia, 475(476), 477-491.

Pendón, J. G., Morales, J. A., Borrego, J., Jiménez, I., \& Lopez, M. (1998). Evolution of estuarine facies in a tidal channel environment SW Spain: Evidence for a change from tide-to wave-domination. Marine Geology, 147, 43-62.

Pérez-Arlucea, M. M., Álvarez, P., \& Rubio, B. (2007). Holocene evolution of estuarine and tidal-flat sediments in San Simón Bay. Journal of Coastal Research, 50, 163-167.

Pozo, M., Ruiz, F., Carretero, M. I., Rodríguez Vidal, J., Cáceres, L. M., Abad, M., et al. (2010). Mineralogical assemblages, geochemistry and fossil associations of Pleistocene-Holocene complex siliciclastic deposits from the Southwestern Donana National Park (SW Spain): A palaeoenvironmental approach. Sedimentary Geology, 225, 1-18.

Reimer, P. J., Bard, E., Bayliss, A., Beck, J. W., Blackwell, P. G., Ramsey, C. B., et al. (2013). INTCAL13 and marine13 radiocarbon age calibration curves $0-50,000$ years cal BP. Radiocarbon, 55, $1869-1887$.

Rodríguez-Ramírez, A., Ruiz, F., Cáceres, L. M., Rodríguez-Vidal, J., Pino, R., \& Muñoz, J. M. (2003). Analysis of the recent storm record in the southwestern Spanish coast: Implications for littoral management. The Science of the Total Environment, 303, 189-201.
Röth, J., Mathes-Schmidt, M., García Jíménez, I., Rojas Pichardo, F.J., Grützner, C., Silva, P.G., et al. (2015). The Baelo Claudia tsunami hypothesis-results from a multi-method sediment analysis of late-Roman deposits (Gibraltar Strait, Southern Spain). 6th INQUA International Workshop on Active Tectonics Paleoseismology and Archaeosismology. Pescina, Italy.

Ruiz, F., Abad, M., Rodríguez Vidal, J., Cáceres, L. M., GonzálezRegalado, M. L., Carretero, M. I., et al. (2008). The geological record of the oldest historical tsunamis in southwestern Spain. Rivista Italiana di Paleontologia e Stratigrafia, 114, 147-156.

Ruiz, F., Borrego, J., González-Regalado, M. L., López-González, N., Carro, B., \& Abad, M. (2009). Interaction between sedimentary processes, historical pollution and microfauna in the Tinto estuary (SW Spain). Environmental Geology, 58, 779-783.

Ruiz, F., González-Regalado, M. L., Borrego, J., Abad, M., \& Pendón, J. G. (2004a). Ostracoda and Foraminifera as short-term tracers of environmental changes in very polluted areas: The Odiel Estuary (SW Spain). Environmental Pollution, 129, 49-61.

Ruiz, F., Rodríguez Ramírez, A., Cáceres, L. M., Rodríguez Vidal, J., Carretero, M. I., Clemente, L., et al. (2004b). Late Holocene evolution of the southwestern Doñana Nacional Park (Guadalquivir Estuary, SW Spain): A multivariate approach. Palaeogeography, Palaeoclimatology, Palaeoecology, 204, 47-64.

Ruiz, F., González-Regalado, M. L., Pendón, J. G., Abad, M., Olías, M., \& Muñoz, J. M. (2005a). Correlation between foraminifera and sedimentary environments in recent estuaries of southwestern Spain: Applications to Holocene reconstructions. Quaternary International, 140-141, 21-36.

Ruiz, F., Rodríguez-Ramírez, A., Cáceres, L. M., Rodríguez Vidal, J., Carretero, M. I., Abad, M., et al. (2005b). Evidence of highenergy events in the geological record: Mid-Holocene evolution of the southwestern Doñana National Park (SW Spain). Palaeogeography, Palaeoclimatology, Palaeoecology, 229, 212-229.

Shaw, J., You, Y., Mohrig, D., \& Kocurek, G. (2015). Tracking hurricane-generated storm surge with washover fan stratigraphy. Geology, 43, 127-130.

Sherwood, A. M., \& Nelson, C. S. (1979). Surficial sediments of Raglan Harbour. New Zealand Journal of Marine and Freshwater Research, 13, 475-496.

Silva, P. G., Giner-Robles, J. L., Reicherter, K., Rodríguez-Pascua, M. A., Grützner, C., García Jiménez, I., et al. (2016). Los terremotos antiguos del conjunto arqueológico romano de Baelo Claudia (Cádiz, Sur de España): Quince años de investigación arqueosismológica. Estudios Geológicos, 72, 119-143.

Stiner, M. C. (1999). Palaeolithic mollusc exploitation at Riparo Mochi (Balzi Rossi, Italy): Food and ornaments from the Aurignacian through Epigravettian. Antiquity, 73, 735-754.

Sullivan, M., \& O'Connor, S. (1993). Middens and cheniers: implications of Australian research. Antiquity, 67, 776-778.

Van Calsteren, P., \& Thomas, L. (2012). Quantitation of protactinium, $231 \mathrm{~Pa}$ in abyssal carbonate. Journal of Analytical Atomic Spectrometry, 27, 952-956.

Vilas, F., \& Arche, A. (1987). Llanura de cheniers en la Bahía de San Sebastián, Tierra del Fuego (Argentina). Acta Geologica Hispanica, 21-22, 245-251.

Wiese, F. (2009). Söhlde Formation (Cenomanian, Turonian) of NW Germany: Shallow marine pelagic red beds. Society for Sedimentary Geology, Special Publication, 91, 153-170.

Zazo, C., Goy, J. L., Somoza, L., Dabrio, C. J., Belluomini, G., Improta, S., et al. (1994). Holocene sequence of sea-level fluctuation in relation to climatic trends in the Atlantic-Mediterranean linkage coast. Journal of Coastal Research, 10, 933-945. 


\section{Affiliations}

María L. González-Regalado $\cdot$ Paula Gómez ${ }^{1,8} \cdot$ Francisco Ruiz $^{1,8} \cdot$ Luis M. Cáceres $^{1,8} \cdot$ María J. Clemente $^{1,8}$. Joaquín Rodríguez-Vidal',8 $\cdot$ Antonio Toscano ${ }^{1,8} \cdot$ Guadalupe Monge $^{2} \cdot$ Manuel Abad $^{3,8} \cdot$ Tatiana Izquierdo $^{3,8}$. Antonio M. Monge Soares ${ }^{4}$. Juan M. Campos ${ }^{5,8}$ • Javier Bermejo ${ }^{5,8}$ • Aranzazu Martínez-Aguirre ${ }^{6} \cdot$ Gloria I. López $^{7}$

1 Departamento de Ciencias de la Tierra, Universidad de Huelva, Avda. Tres de Marzo s/n, 21071 Huelva, Spain

2 Departamento de Cristalografía, Mineralogía y Química Agrícola, Universidad de Sevilla, 41071 Seville, Spain

3 Universidad de Atacama, Avda. Copayapu 485, Copiapó, Chile

4 Centro de Ciências e Tecnologias Nucleares (C2TN), Instituto Superior Técnico, Universidade de Lisboa, Estrada Nacional 10 (k 139.7), Bobadela LRS, 2695-066 Lisbon, Portugal
5 Departamento de Historia I, Universidad de Huelva, Avda. Tres de Marzo s/n, 21071 Huelva, Spain

6 Departamento de Física Aplicada I, EUITA, Universidad de Sevilla, Crta. Utrera km 1, 41013 Seville, Spain

7 Centro Nacional de Investigación sobre la Evolución Humana, Paseo Sierra de Atapuerca 3, 09002 Burgos, Spain

8 Centro de Investigación en Patrimonio Histórico, Cultural y Natural (CIPHCN), Universidad de Huelva, Facultad de Humanidades, Avda. Tres de Marzo s/n, 21071 Huelva, Spain 